\title{
SISTEM KONTROL PADA KENDARAAN RODA DUA BERPENGGERAK HIBRIDA
}

\author{
Didi Widya Utama ${ }^{1)}$, Kennard Dhammabhakti' ${ }^{1)}$ dan Asrul Aziz ${ }^{2)}$ \\ ${ }^{1)}$ Program Studi Teknik Mesin, Fakultas Teknik Universitas Tarumanagara \\ ${ }^{2)}$ Fakultas Sains dan Teknologi Universitas Islam Negeri Syarif Hidayatullah \\ e-mail: didi_wu@hotmail.com, kennardsetiawan@yahoo.com, azizasrul@yahoo.com
}

\begin{abstract}
This hybrid motorcycle design is to combine $5.65 \mathrm{~kW}$ gasoline engine and $48 \mathrm{~V}$ DC $0.5 \mathrm{~kW}$ electrical brushless motor in serial-parallel type. Master control unit use a microcontroller ATMega16 to control gasoline engine and electrical motor alternately. Speed sensor is placed on the rear wheel to detect the motorcycle's speed. When the motorcycle's speed reaches the top threshold at $30 \mathrm{~km} / \mathrm{h}$, it driven with gasoline engine and when the motorcycle's speed getting lower to the bottom threshold at $5 \mathrm{~km} / \mathrm{h}$, it changes with electrical motor. Battery charged with plug-in system to power supply.
\end{abstract}

Keywords: hybrid motorcycle, microcontroller, speed sensor, battery

\section{PENDAHULUAN}

Kebutuhan sarana transportasi terus meningkat. Maka dari itu, masyarakat memilih untuk menggunakan kendaraan bermotor pribadi. Jenis kendaraan yang lebih banyak dipilih kendaraan bermotor roda dua, karena lebih murah dan mudah digunakan dari jenis kendaraan pribadi lain. Melihat kondisi seperti ini, dapat dipastikan bahwa kendaraan bermotor roda dua menghasilkan emisi gas buang yang banyak. Agar mengurangi masalah ini, maka digunakan teknologi hybrid.

Kendaraan hybrid adalah kendaran yang menggunakan dua sumber energi untuk menghasilkan putaran pada poros penggerak. Kedua energi tersebut berasal dari bensin untuk motor bakar dan listrik untuk motor listrik. Sistem penggerak hybrid dapat menghemat bahan bakar fosil kurang lebih 31\% [5]. Secara garis besar, motor bakar dan motor listrik bekerja secara bergantian. Dengan demikian, maka diperlukan suatu sistem kontrol. Sistem kontrol menggunakan sebuah mikrokontroler yang berfungsi sebagai pusat pengendali sistem berdasarkan input sensor pada kendaraan tersebut.

Tujuan dari perancangan ini adalah merancang sistem kontrol untuk mengatur saat pemakaian motor listrik dan motor bakar pada kendaraan hibrida roda dua dan mendapatkan efisiensi dari pemakaian bahan bakar.

\section{PERANCANGAN KENDARAAN RODA DUA BERPENGGERAK HIBRIDA}

Perancangan kendaraan roda hibrida ini berupa modifikasi dari sepeda motor konvensional. Roda belakang dari sepeda motor diganti dengan motor listrik 0.5kW/48V DC brushless dengan penambahan adapter untuk sproket sehingga daya $5.65 \mathrm{~kW}$ motor bakar dapat ditransmisikan ke roda. Penambahan box di belakang sepeda motor digunakan untuk penyimpanan baterai seperti terlihat pada Gambar 1.

Hasil dari perancangan memiliki dimensi luar (P x L x T) 1993 x 712 x 1092 mm. Jarak antar roda $1260 \mathrm{~mm}$ dan ground clearance $83 \mathrm{~mm}$. Posisi sensor kecepatan diletakkan $110 \mathrm{~mm}$ di depan sumbu roda belakang. Baterai terletak pada box belakang sejauh $660 \mathrm{~mm}$ di belakang sumbu roda belakang. Mikrokontroler dan rangkaian elektronik yang lain selain voltage divider diletakkan di dalam bagasi sedangkan voltage divider terdapat di dalam box penyimpanan baterai, seperti terlihat pada Gambar 2. Voltage divider digunakan untuk membaca tegangan baterai. 


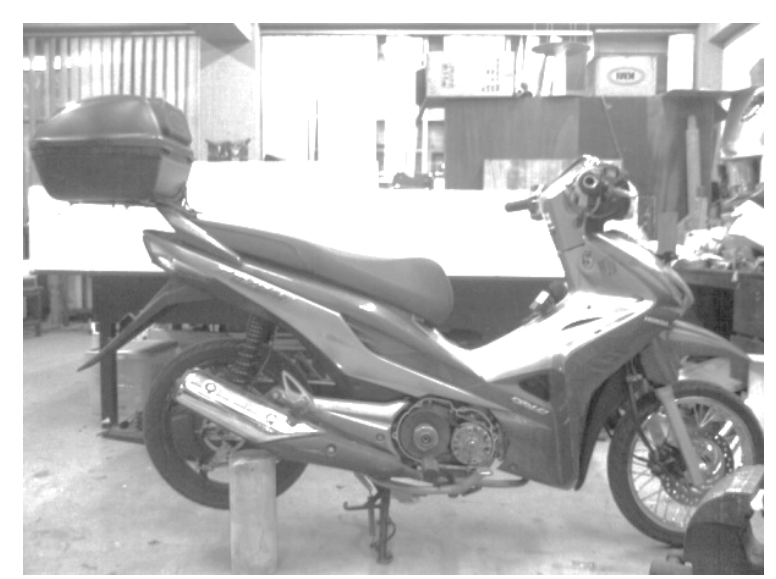

Gambar 1. Hasil perancangan sepeda motor hibrida

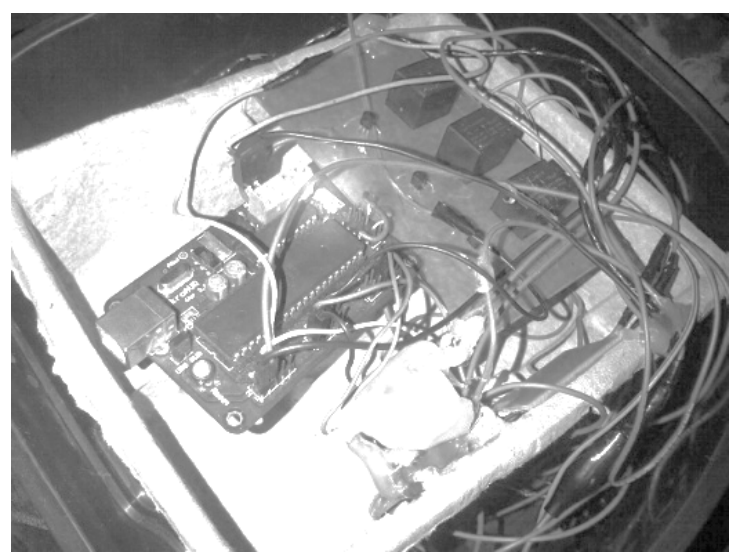

(a)

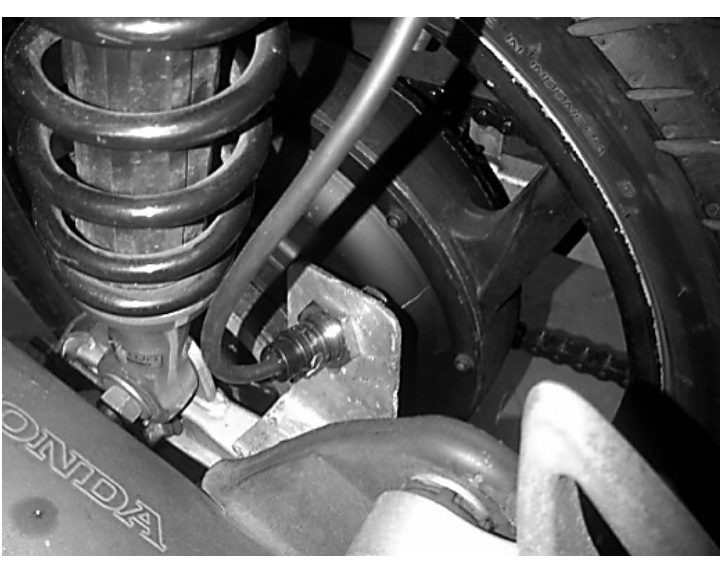

(b)

Gambar 2. Letak (a) mikrokontroler dan (b) sensor kecepatan

\section{PERANCANGAN SISTEM KONTROL}

Pada saat awal menyalakan sepeda motor, maka mikrokontroler membaca tegangan pada baterai. Jika tegangan di bawah 47V, maka motor bakar dinyalakan untuk menggerakan sepeda motor. Jika tegangan di atas 47V, maka motor listrik dinyalakan. Batas atas kecepatan untuk pergantian sistem penggerak adalah $30 \mathrm{~km} / \mathrm{jam}$ dan batas bawah kecepatan adalah $5 \mathrm{~km} / \mathrm{jam}$. Saat kecepatan di atas $30 \mathrm{~km} / \mathrm{jam}$, sensor kecepatan pada roda belakang mendeteksi perubahan kecepatan terjadi dan diproses di mikrokontroler. Selanjutnya, dynamo starter diaktifkan untuk menjalankan motor bakar dan motor listrik dimatikan. Sehingga sepeda motor melaju dengan motor bakar pada kecepatan tinggi. Saat kecepatan sepeda motor turun di bawah $5 \mathrm{~km} / \mathrm{jam}$, maka motor bakar dimatikan dan motor listrik dinyalakan. Pengisian baterai dilakukan dengan cara plug-in ke sumber tegangan listrik. Rangkaian sistem control dapat dilihat pada Gambar 3.

\section{PENGUJIAN}

Pengujian dilakukan dalam dua kondisi:

1. Kondisi statis: pengukuran dilakukan saat kendaraan diam dengan cara kendaraan digantung pada roda belakangnya, hasil pengujian ini dapat dilihat pada Gambar 4.

2. Kondisi dinamis: pengukuran dilakukan saat kendaraan berjalan dengan beban satu penumpang, hasil pengujian dapat dilihat pada Gambar 5.

Kedua kondisi diuji dengan menggunakan penggerak hybrid. Pengujian dinamis dilakukan di Jl. Taman Golf Boulevard, Tanggerang dengan kondisi jalan tidak ramai dan rata-rata kecepatan kendaraan 40km/jam. Jarak lintasan yang digunakan sekitar 1,12 km. 


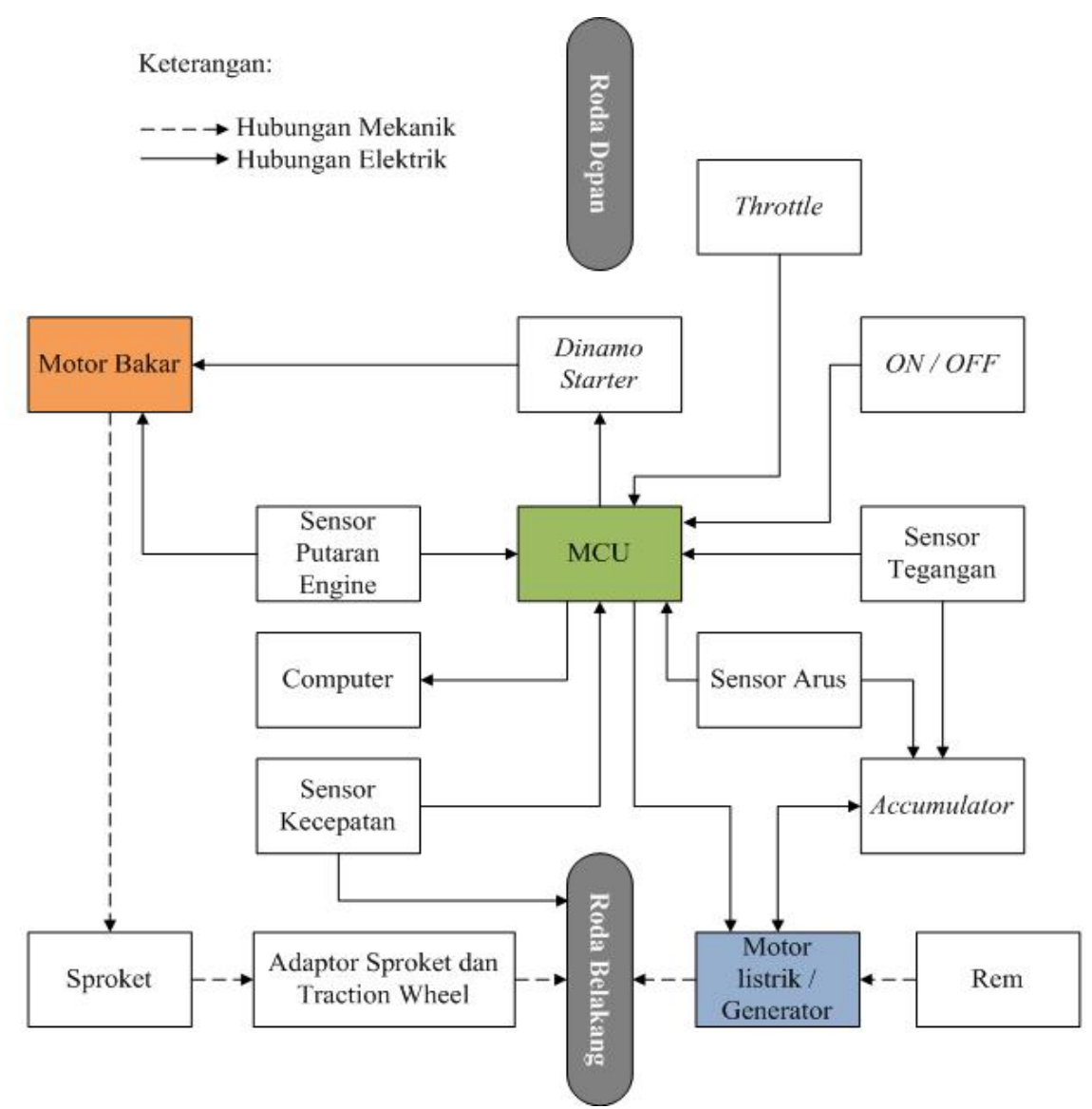

Gambar 3. Diagram sistem kontrol kendaraan roda dua berpenggerak hibrida

Efisiensi bahan bakar diukur dengan cara mengukur pemakaian bensin pada saat sepeda motor melaju dengan penggerak 100\% motor bakar dan pemakaian bahan bakar saat sepeda motor melaju dengan penggerak hybrid. Kontur jalan yang digunakan untuk hasil dan pengujian dinamis dapat dilihat pada Gambar 6.

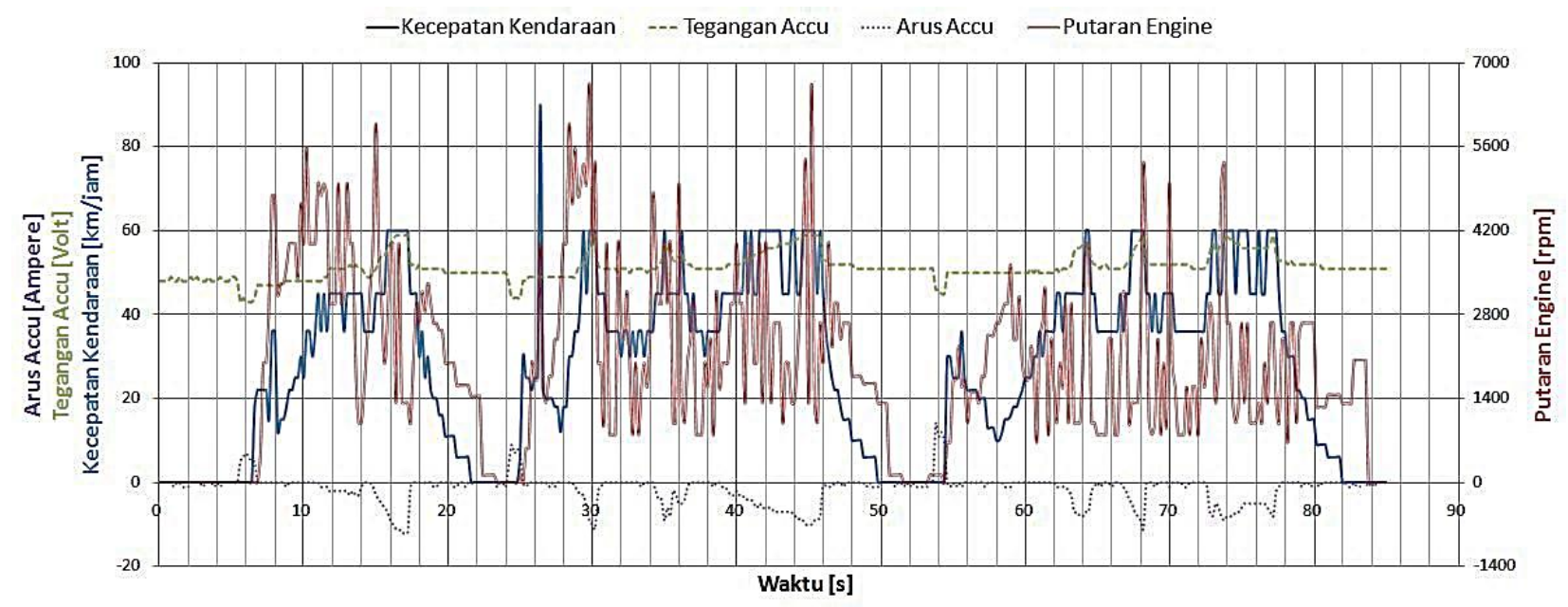

Gambar 4. Hasil pengujian statis

Konsumsi bahan bakar saat sepeda motor melaju dengan penggerak motor bakar sebesar 258 ml. Sedangkan saat sepeda motor melaju dengan penggerak hybrid, konsumsi bahan bakar sebesar $192 \mathrm{ml}$. Dengan demikian, sepeda motor dapat menempuh jarak hingga 44,58 km/lt saat menggunakan penggerak motor bakar dan mencapai $60 \mathrm{~km} / \mathrm{lt}$ saat menggunakan penggerak hybrid. 
Pengisian aсcu akibat arus balik oleh putaran motor bakar terukur saat putaran motor bakar mancapai $4787 \mathrm{rpm}$ pada kondisi statis dan $6981 \mathrm{rpm}$ pada kondisi dinamis.

Pada pengujian statis, energi listrik yang digunakan sebesar 0,0352 Wh dan pada pengujian dinamis didapatkan energi listrik yang digunakan sebesar 0,7104 Wh/km.

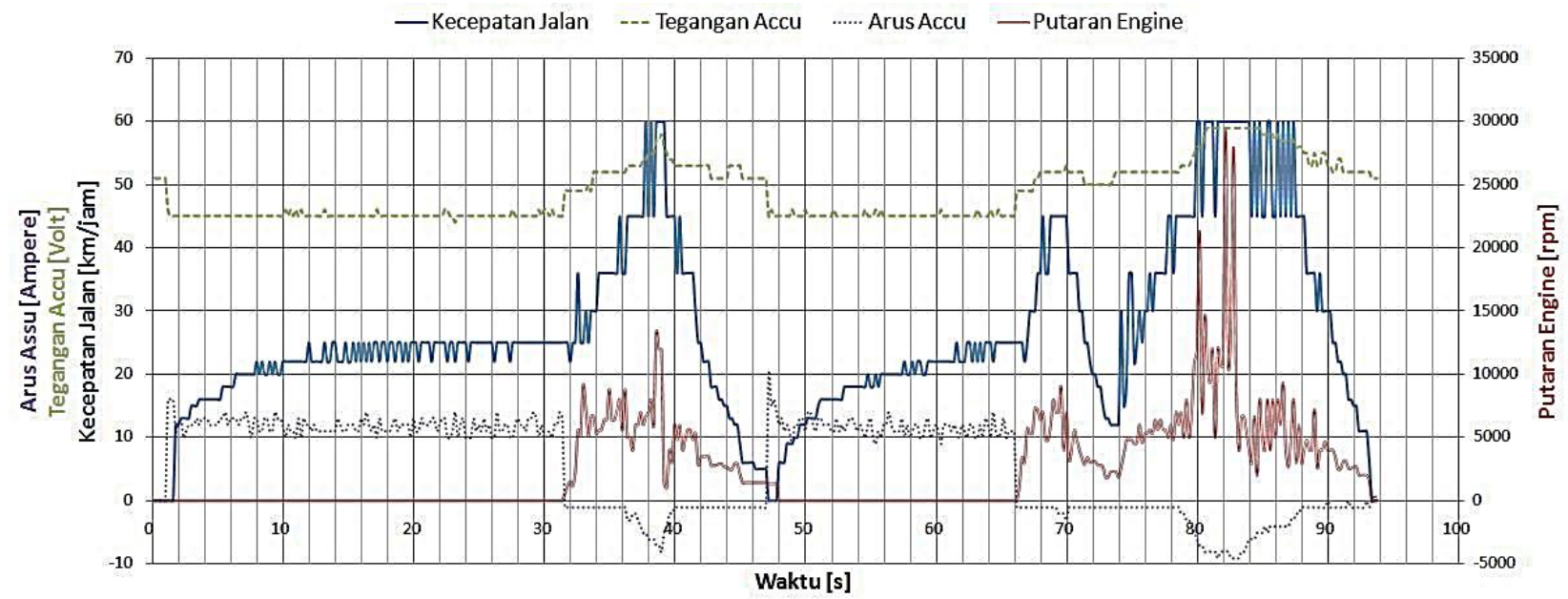

Gambar 5. Hasil pengujian dinamis

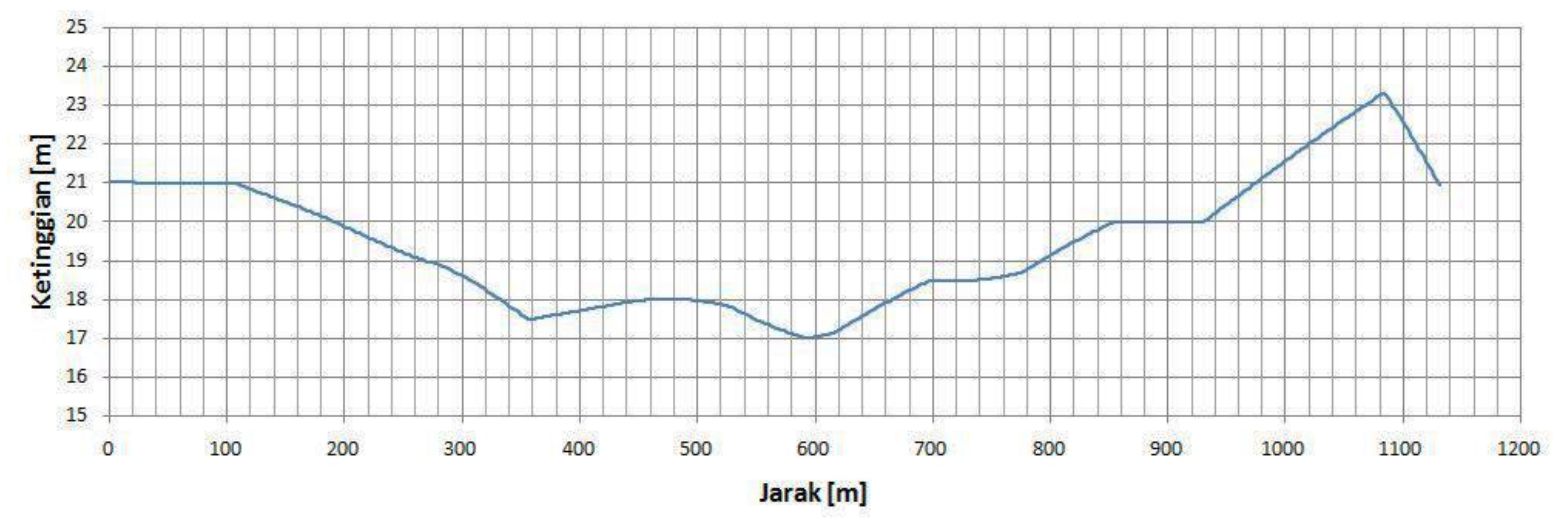

Gambar 6. Kontur jalan yang digunakan untuk pengujian dinamis [7]

\section{KESIMPULAN}

Sistem kontrol kendaraan roda dua hybrid yang dirancang mampu mengendalikan pemakaian motor bakar dan motor listrik sesuai dengan perubahan kecepatan yang telah ditentukan. Saat kecepatan lebih dari $30 \mathrm{~km} / \mathrm{jam}$ maka sepeda motor menggunakan motor bakar sebagai penggerak dan saat sepeda motor melaju kurang dari $5 \mathrm{~km} / \mathrm{jam}$ maka motor listrik digunakan sebagai penggerak. Penggunaan teknologi berpenggerak hybrid pada sepeda motor ini dapat menghemat pemakaian bahan bakar hingga 34,58\%.

\section{DAFTAR PUSTAKA}

[1] Allen E. Fuhs. Hybrid Vehicles and the Future of Personal Transportation. USA: CRC Press. 2009.

[2] Chris Mi, Abul Masrur, and Wenzhong Gao. Hybrid Electric Vehicles: Principles and Applications with Practical Perspectives. USA: John Wiley \& Sons, Ltd. 2011.

[3] John M. Miller. Propulsion Systems for Hybrid Vehicles. UK: IET Power and Energy. 2008.

[4] Mehrdad Ehsani, Yimin Gao, Ali Emadi. Hybrid Electric and Fuel Cell Vehicles. USA: CRC Press. 2010. 
[5] Danardono A. Sumarsono, Didi Widya Utama, Gandjar Kiswanto. Design and Development of Simple Control System for Small Hybrid Electric Vehicle. Journal of Applied Mechanics and Materials, Vol. 165, pp. 73-77. 2012.

[6] Erny Listijorini, I Nyoman Sutantra, Bambang Sampurno. Pengembangan Teknologi Pengendali Switching Pada Kendaraan Hybrid Roda Dua. Seminar Nasional Pascasarjana X. Surabaya. 2010.

[7] Informasi dari www.geocontext.org 